\title{
An Application of the Theory of Planned Behavior to Predict the Behavior of INTERNATIONAL FAST FOOD RESTAURANTS' GUESTS TOWARDS NEgATIVE PUBLICITY
}

\section{Mohamed Ahmed Ali \\ Faculty Of Tourism And Hotels, Minia University, Egypt}

\begin{abstract}
Negative Publicity is the contrary publicity that an establishment may suffer, which may lead to potentially catastrophic consequences. It results in the distortion of the firm's reputation among its consumers and competitors. It may damages business. This research studies the impact of negative publicity of the international fast food restaurants' guests by applying the theory of planned behavior. Using structural equation modeling (SEM) to examine the data collected from a sample of 313 international fast food restaurants' guests. The results indicate that the final integrated model of the study explains $49 \%$ of the variance of the intention of international fast food restaurants' guests towards negative publicity and 5\% of the variance of the behavior. Attitude, subjective Norms, perceived behavioral control would positively affect intention to visit the international fast-food restaurants that have negative publicity. Intention had a positive impact on behavior of international fast food restaurants' guests towards negative publicity. The results offer significant implications for international fast food management and are likely to stimulate further research in the area predicting the behavior of hospitality establishments' guests towards negative publicity.
\end{abstract}

KEYWORDS: Theory of Planned Behavior, Negative Publicity, International Fast Food Restaurants, Attitude, Subjective Norms, Perceived behavioral control, Intention.

\section{INTRODUCTION}

Publicity is the fourth main tool in promotional mix. Publicity is generally free of cost and cannot be organized. It may be positive or negative.It is a very powerful tool of marketing promotion. It can be 
done by continuous press releases, conferences, letters to the editor, features, articles, photos and videos. It is not directly paid for or run under recognized sponsorship. Publicity is in the form of story, announcement, editorial about an establishment, its products or services. It is not paid by the sponsor (Khan, 2006).

The effect of negative publicity on business has been appeared clearly. Negative information about brands and organizaions is widely predominant in the market. The commitment is a significant moderator of customer response to negative information. Specifically, the response patterns of high- and low-commitment customers are very dissimilar. Customers who are committed to a product mechanically counter argue negative info about that product. These defensive processes relieve the ill belongings of that information in that they decrease the probability of attitude degradation. Low commitment customers, in reverse, counter argue the negative info to a slighter degree. Additionally eventhough lowcommitment customers seem to like the productas much as the highcommitment consumers do, they display more attitude change and increased attitude uncertainty upon exposition to negative info about it. This attitude retreating is driven by their perceptions of the diagnosticity of negative info (Sherrell, Reidenbach, Moore, Wagle, \& Spratlin, 1985).

Researchers always try to understand and predict the human behavior (Holdershaw \& Gendall, 2008). Understanding human behavior is a hard task. It can be declared at many levels, from anxiety with physiological processes at one ultimate to concentration on social organizations at the other. Social and personality psychologists have focused on an intermediate level, the entirely functioning individual whose processing of available information mediates the impacts of biological and environmental factors on behavior. Concepts referring to behavioral dispositions, such as social attitude and personality trait, have played a vital role in these attempts to predict and understand human behavior (Ajzen, 1991).

\section{Publicity}

The marketing promotional mix comprises advertising, sales promotion, public relations and publicity, personal selling, and direct marketing (Kotler, 2002). Publicity provides numerous advantages. In addition to the low cost, the material presented is not familiar as paid advertising per se because it occurs in an journalistic setting that 
makes it appear to have been created by approval of the journalistic staff. The material thus has more trustworthiness, and customers tend to accept it as news information rather than as advertising. This perception is chiefly beneficial in countries where it is difficult to buy commercial time or advertising space (Onkvisit \& Shaw, 2004).

Publicity is a non-paid form of communications. Unlike advertising which paid to the media. It refers to non-personal communication regarding an establishment, a person, product, service or an idea not directly paid or under recognized sponsorship. It frequently comes in the form of news, story, report or announcement about an establishment product or service. Publicity may contain photos and videos (Khan, 2006; Tartamella, 2001).

The appeal of publicity is based on three significant advanatages: (1) high trustworthiness (news stories and features are more reliable and credible than ads); (2) capability to catch purchasers off guard (reach prospects who prefer to avoid sales people and ads); and (3) dramatization (the potential for dramatizing an organization or product) (Kotler, 2002). Negative publicity does more than shape perceptions; it may have impacts on various forms of public support that would significantly affect an establishment's current and future commitments (Kim, Carvalho, \& Cooksey, 2007).

\section{Negative Publicity}

Publicity may play an significant role in enhancing or damaging the image of a brand. So, negative publicity does more than shape persons' perceptions; it may have influences on different forms of public support that would meaning fully influence on an organization such as reducing consumption (Kim et al., 2007; Youn, Lim, \& Jin, 2012).

Customers focus on negative information because it is more diagnostic. The customer's level of commitment qualifies this impact. Definitely, the negativity impact appears to be more likely when a customer's commitment to brand is low. At high levels of commitment, not only is the negativity impact absent, but also customers actually considered positive information about that brand more diagnostic than negative information about it. This reversal of the negativity impact shows to the powerful nature of commitment as amoderator of communication influences (Sherrell et al., 1985). 
The way organizations face negative publicity has strategic importance as well as ethical implications. The main ethical matter concerns whether organizations admit to brand inadequacies and acknowledge problems or, instead, try to cover up the problems. Brand crises and negative publicity can hit an orgaization at any time. A company response promptly following negative publicity can reduce the loss that will result, loss such as a lessening in the people's confidence in an organization and its products or a major damage in revenues and profits. It is significant to note, however, that not all customers are equally fluctuate by negative publicity about a product or organization. In particular, customers who hold more positive evaluations of an organization are more likely to confront negative publicity about that organization and thus are less likely to experience diminished evaluation following negative publicity. On the other hand, those who are less loyal are especially oversensitive to the converse impacts of negative publicity (Shimp, 2007).

No establishment wishes negative publicity. Without the appropriate handling of publicity, a situation may worsen. Marketers should cautiously review how the establishment was able to turn the negative publicity around and recover empathy and trust. Based on these experiences, there are several "do's" and"don'ts" that should be followed (Onkvisit \& Shaw, 2004). When negative publicity occurs, the public relations (PR) department acts as a troubleshooter. The best PR departments spend time counseling top management to assume positive programs and to reduce doubtful practices so that negative publicity does not occur in the first place (Kotler, 2002).

\section{Negative Publicity in Hospitaity Industry}

The main objective of the mass media is to communicate news to the general public. Tourists are likely to trust mass media and are influenced by it in their decision-making process. Although tourists have dissimilar perceptions and motivational factors, the mass media plays a vital role in travel behavior because it is influencing the tourist's decisions. Tour Operators are evenly reminded that a positive perception is possible to create through the dialectic of different narratives in the society. (Lexow \& Edelheim, 2004).

One of the main advantages of publicity as a medium of promotion is its credibility. The news is written by a neuter third party. An advertising clearly presents the advertiser's point of view. But a news article, even if it is an edited version of an establishment's press 
release, is seen by its readers as objective and true. In addition, with the rising cost of advertising, it is in an operation's best interest to present information in a news format and encourage press coverage. To gain the media's attention to an operation's story, however, is not easy. hospitality managers do not recognize the concerns and interests of the media and present stories that are of relevance to the operators, but of very little worth to the media. They simply do not know what news is praiseworthy. Operators should look at each story from the viewpoint of the media's targeted viewers (Hsu \& Powers, 2002).

For larger establishments with numerous hospitality outlets or brands the problem of a unit indecline is exacerbated by the negative publicity, which can damage brand image of successful outlets in other stages of the life cycle. Some hoteliers are so eager to be in the news they forget the purpose of PR activity, which is to generate positive publicity for the business. Unsuitable stunts can generate important amounts of irrelevant or even negative publicity, which weakens the product's position in the market. Minority of consumers who complain can become maniac with what they believe to be the establishment's inappropriate response to their complaint. These estranged persons make public the service establishment's deterioratings in newspaper advertisements. They encourage other unhappy consumer to complain, and by generating substantial amounts of negative publicity in the media, can damage the establishment notably. Establishments like McDonald's and Starbucks have suffered from this type of publicity (Bowie \& Buttle, 2004).

Nowadays, the Internet provides low-cost opportunities for terrorist consumers to set up anti-company websites to spread their criticisms to others. Unhappy consumers can also record the proof of their displeasure by taking photographs, or filming the situation on a camcorder. In extreme cases the consumers can give the evidence to the media, which ensures widespread negative publicity about the complaint for the establishment. There are also examples of consumers prosecution hospitality establishments for damages caused by unsatisfactory service. This type of negative publicity is very damaging to the establishments' reputation, and could even lead to a breakdown in consumer confidence, with catastrophic consequences for the establishment (Bowie \& Buttle, 2004). 


\section{Theory of Planned Behavior}

The Theory of Planned Behavior (TPB) provided clear definitions of concepts and is reinforced by an inclusive body of correlational indication. The TPB provided a clear and well-organized framework for use in the study of a human's intent to perform context-specific actions (Röttger et al., 2017; Russo et al., 2015). TPB is one of the most well-established psychological theories of human decision making (Al, Locke, \& Boulanouar, 2018; Thorhauge, Haustein, \& Cherchi, 2016). TPB is being more and more applied in the wideranging of consumer research studies (Frater, Kuijer, \& Kingham, 2017; Ho, Im, Eun, \& Severt, 2018; Hoeksma, Gerritzen, Lokhorst, \& Poortvliet, 2017; Lin, Oveisi, Burri, \& Pakpour, 2017; Rezaei, Mianaji, \& Ganjloo, 2018; Zhou, Romero, \& Qin, 2016). It is one of the most extensively used and influential theoretical model for the attitude-behavior relationship (Li, Zuo, Cai, \& Zillante, 2018).

TPB clarifies human behaviors through a cognitive approach, which center on their attitudes and beliefs (Halder, Pietarinen, HavuNuutinen, Pöllänen, \& Pelkonen, 2016). TPB is a psycho-social model of human behavior, focused on predicting and understanding of clearly defined behaviors (Cameron, Ginsburg, Westhoff, \& Mendez, 2012; Cheung \& To, 2017; Jiang, Zhao, Sun, Zhang, \& Zheng, 2016; López-Mosquera, 2016; Shi, Fan, \& Zhao, 2017). Furthermore, TPB is one of the most predictive persuasion models in understanding behavioral intentions (Raziuddin \& Vaithianathan, 2018). It can predict $39 \%$ to $42 \%$ of the variance in intention (Hoeksma et al., 2017).

TPB included some of the central constructs in the social and behavior sciences, and it sets these constucts in a way that permits prediction and understanding of specific behaviors in identified contexts. Attitudes toward the behavior, Subjective Norms with respect to the behavior, and perceived control over the behavior are usually found to predict behavioral intentions with a high degree of precision. In turn, these intentions, in combination with perceived behavioral control, can account for a significant percentage of variance in behavior (Ajzen, 1991).

The theory of planned behavior indicated that, prediction of intention depends on three different processes: 1) attitude, 2) subjective norms and 3) perceived behavior control. Attitude declares how people think and believe, which relates to expectations of the behavior. Subjective norms relates to the support provided or not provided by an person's 
family, friends or significant other who meaning fully effects that individual's behavior.

Perceived behavior control refers to an person's feelings about the capability to do the intended behavior. Generally, TPB declares that when a person perceives an activity as pleasurable and providing decent benefits, the person receives support and encouragement from other persons who are already involved in that behavior, and the person makes assumptions concerning his or her own capability to complete the task. Then, there is stronger intention to achieve that task, which leads to actual performance of that particulart ask (Ajzen, 1991). Attitudes are supposed to play a significant role in human behaviour theory as the vital link between what individuals think and what they do (Holdershaw \& Gendall, 2008). Fig. 1. declares the basic theoretical framework of TPB.

Fig 1 The theory of the planned behavior

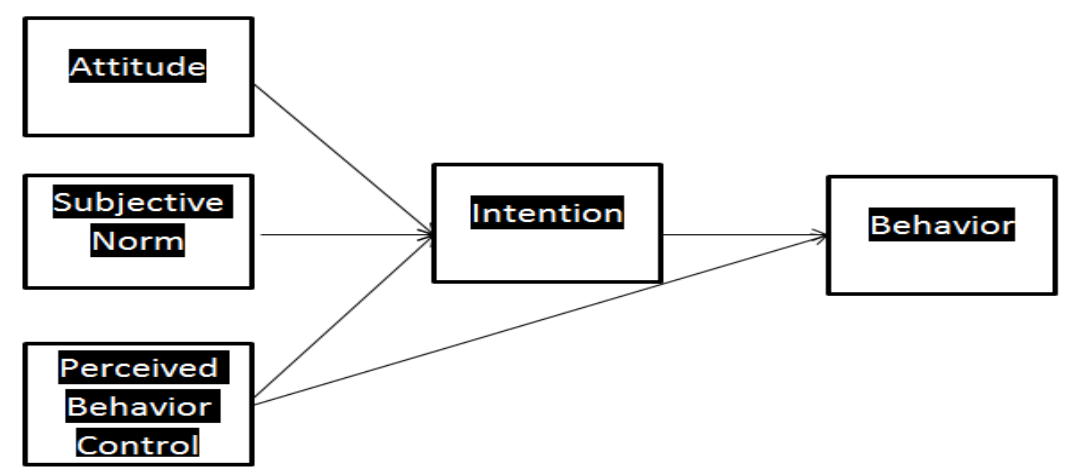

Adopted from Ajzen, 1991

Based upon the above discussions, the hypotheses in the study were as follows:

H1. The attitude of guests towards negative publicity has a significant positive impact on their intention to visit international fast food restaurants.

H2. Subjective norms of guests have a significant positive impact on their intention to visit international fast food restaurants.

H3. Perceived behavior control of guests has a significant positive impact on their intention to visit international fast food restaurants.

H4: The intention to visit international fast food restaurants has a 
significant positive impact on visiting the international fast food restaurants

H5: Perceived behavior control of guests has a significant positive impact on visiting the international fast food restaurants

\section{RESEARCH METHODOLOGY}

The study conducted an empirical study on predicting the behavior of international fast food restaurants' guests in order to test the proposed hypotheses using the quantitative approach. Quantitative data were collected using questionnaires.

The target population of the current research includes the guests of international fast food restaurants e.g., (Kentucky fried chicken, McDonald's, Burger King, Hardee's, Pizza Hut). The researcher used TPB questionnaire (Ajzen, 1991) and translated it into Arabic. A pilot study was conducted to examine the validity and reliability of the study instrument. A group of thirty of fast food restaurants' guests and fifteen of experts were asked to review the questionnaire. Their comments resulted in modification in terms of its readability clearness of Arabic translation. The questionnaire was available online between April 27, 2018 and July 31, 2018. The questionnaire was published in social media groups randomly with a request for participation and providing respondents with information for the purpose of the study, the estimated time to fill out the questionnaire, and a banner with a hyperlink connecting to web questionnaire. A total of 313 responses are valid for analysis. Table 1 lists the sample demographics.

Table 1 Demographic attributes of the respondents

\begin{tabular}{|c|c|c|}
\hline Characteristic & \multicolumn{2}{|c|}{ N=313 } \\
\hline & Frequency & Percentage \\
\hline Gender & & \\
\hline Female & 127 & 40.6 \\
\hline Male & 186 & 59.4 \\
\hline Age & & \\
\hline Under 20 years & 29 & 9.3 \\
\hline 20-36 years & 254 & 81.2 \\
\hline 37-52 years & 28 & 8.9 \\
\hline
\end{tabular}




\begin{tabular}{|c|c|c|}
\hline 53 years and over & 2 & 0.6 \\
\hline Marital Status & & \\
\hline Single & 201 & 64.2 \\
\hline Married & 110 & 35.1 \\
\hline Divorced & 1 & 0.3 \\
\hline Widow & 1 & 0.3 \\
\hline Education & 116 & 37.1 \\
\hline High School & 131 & 41.9 \\
\hline Bachelor & 39 & 12.5 \\
\hline Master & 27 & 8.5 \\
\hline Ph.D. & & \\
\hline Career & 48 & 15.3 \\
\hline Teaching Field & 7 & 2.2 \\
\hline Medical Field & 34 & 10.9 \\
\hline Tourism and Hotels Sector & 79 & 25.2 \\
\hline Student & 35 & 11.2 \\
\hline Governmental Employees & 5 & 1.6 \\
\hline Housewife & 105 & 33.6 \\
\hline Other & & \\
\hline
\end{tabular}

When determining the sample size for an SEM research, 10-20 participants per independent variable is recommended (Teo, Tsai, \& Yang, 2013; Wolf, Harrington, Clark, \& Miller, 2015). Since 313 cases were collected, the current study sample size considers enough for consecutive analyses with structural equation modeling.

\section{QUESTIONNAIRE DESIGN}

The questionnaire for this research was divided into six main parts; the first one consisted of respondents' demographics. From the second part to sixth part questions to measure attitude, subjective norms, perceived behavior control, intention, and behavior respectively were asked. It should be declared that all constructs have a reflective measurement. The option to manage and remove duplicate responses by Internet Protocol was used to avoid duplicate ones. The research model has five constructs, each having items that are measured by 7 point Likert scale. 
The researcher applied the partial least squares (PLS-SEM), used Warp PLS 6.0 programme to examine the validity of the measures and test the hypotheses. PLS lessens the endogenous variables residual variances, and it is also a suitable approach to deal with multiple relationships at the same time. This technique does not require a normal distribution (Dow, Watson, Greenberg, \& Greenberg, 2012; Hair, Hult, Ringle, \& Sarstedt, 2016; Lowry \& Gaskin, 2014), finally, PLS is also recommended for testing complex models. Moreover, variables with fewer items can be used (Henseler, Ringle, \& Sinkovics, 2009; Kovacevic, Abdi, \& Beaton, 2013).

\section{RESULTS}

To evaluate the conceptual framework by using PLS, the evaluation of the measurement model (outer model) and structural model (inner model) were conducted respectively.

\section{MEASUREMENT MODEL}

Skewness and kurtosis are calculated to test the criterion of multivariate normality (Dufour, Khalaf, \& Beaulieu, 2003; Henry C. Thode, 2002). Therefore, the researcher calculated them for all the constructs (see table 2). These results indicated that there is no departure from normality. Usually, the evaluation of the outer model is the critical first step in quantitative, positivist research. Examining the reliability and validity of results of the measurement model need to be conducted to ensure the quality of research results (Anney, 2014; Arnhold, 2010) (see tables 3 and 4). Table 3 declares that all constructs have Cronbach's alpha and composite reliability more than 0.7, and all constructs have average variance extracted (AVE) more than 0.5 . Therefore, these results support convergent validity of the research model.

The researcher calculated variance inflation factors (VIFs) as measures of multicollinearity. A VIF larger than 10 is a reason for concern (Kamaruddin \& Abeysekera, 2013; O'Brien, 2007; Wooldridge, 2009). All constructs of study had variance inflation factors (VIF) values less than 5 (see table 3), confirming that the measurement model results were not negatively affected by the items multicollinearity.

Discriminant validity was examined by calculating two steps. The first step of discriminant validity analysis was examined by 
calculating cross loadings. In cross loadings calculation, the loading of each item is expected to be higher than of all its all cross loadings (Henseler, Ringle, \& Sarstedt, 2014; Reyes-Mercado, 2016). Loadings of measurement items (see table 4) declared that all items loaded on to the corresponding latent variable structure and all items show loadings more than 0.7. Secondly, the Fornell and Larcker (1981) criterion was that square root of a construct's AVE is larger than the inter-construct correlation (see table 5). The results were shown in tables 4 and 5 support the discriminant validity of the research model.

Table 2 Descriptive statistics and normality tests of the indicators in the model

\begin{tabular}{|c|c|c|c|c|}
\hline Statistics & Mean & SD & Skewness & Kurtosis \\
\hline \multicolumn{5}{|l|}{ Attitude } \\
\hline $\begin{array}{l}\text { For me, visiting the } \\
\text { international fast-food } \\
\text { restaurants that have } \\
\text { negative publicity would be } \\
\text { pleasant (Attitude1). }\end{array}$ & 3.454 & 1.855 & 0.532 & -0.633 \\
\hline $\begin{array}{l}\text { Overall, my attitude towards } \\
\text { the international fast-food } \\
\text { restaurants that have } \\
\text { negative publicity is positive } \\
\text { (Attitude2). }\end{array}$ & 3.540 & 1.881 & 0.378 & -0.956 \\
\hline $\begin{array}{l}\text { My overall attitude towards } \\
\text { the international fast-food } \\
\text { restaurants that have } \\
\text { negative publicity is } \\
\text { unfavorable (Attitude3). }\end{array}$ & 3.297 & 1.804 & 0.608 & -0.698 \\
\hline $\begin{array}{l}\text { Generally, I have a good } \\
\text { attitude towards the } \\
\text { international } \\
\text { restaurants which have } \\
\text { negative } \\
\text { (Attitude4) }\end{array}$ & 3.406 & 1.788 & 0.564 & -0.604 \\
\hline $\begin{array}{l}\text { Subjective } \\
\text { (SubNorm) }\end{array}$ & & & & \\
\hline
\end{tabular}




\begin{tabular}{|l|l|l|l|l|}
\hline $\begin{array}{l}\text { Most people who are } \\
\text { important to me approve of } \\
\text { visiting the international } \\
\text { fast-food restaurants that } \\
\text { hav negative publicity } \\
\text { (SubNorm1). }\end{array}$ & 3.281 & 1.875 & 0.573 & -0.777 \\
\hline $\begin{array}{l}\text { Most people like me to visit } \\
\text { the international fast-food } \\
\text { restaurants that have } \\
\text { negative publicity } \\
\text { (SubNorm2). }\end{array}$ & & & & \\
\hline $\begin{array}{l}\text { The majority of the people } \\
\text { important to me expect to } \\
\text { visit the international fast- } \\
\text { food restaurants that have } \\
\text { negative publicity } \\
\text { (SubNorm3). }\end{array}$ & 3.278 & 1.814 & 0.718 & -0.478 \\
\hline $\begin{array}{l}\text { Perceived behavioral } \\
\text { control (PerBeCon) }\end{array}$ & & & & \\
\hline $\begin{array}{l}\text { I am confident that I can } \\
\text { visit the international fast- } \\
\text { food restaurants that have } \\
\text { negative publicity } \\
\text { (PerBeCon1). }\end{array}$ & 3.377 & 1.858 & 0.704 & -0.522 \\
\hline $\begin{array}{l}\text { Visiting the international } \\
\text { fast-food restaurants that } \\
\text { have negative publicity is up } \\
\text { to me (PerBeCon2). }\end{array}$ & 3.760 & 1.944 & 0.363 & -1.051 \\
\hline $\begin{array}{l}\text { If I wanted to, I could I can } \\
\text { visit the international fast- } \\
\text { food restaurants which have } \\
\text { negative }\end{array}$ & 3.316 & 1.829 & 0.645 & -0.688 \\
(PerBeCon3). & & & \\
\hline $\begin{array}{l}\text { Intention (Intent) } \\
\text { intend to visit the } \\
\text { international fast-food } \\
\text { restaurants which have } \\
\text { negative publicity (Intent1) }\end{array}$ & 3.581 & 1.845 & 0.424 & -0.926 \\
\hline I have thought about visiting & 3.511 & 1.923 & 0.470 & \\
\hline
\end{tabular}




\begin{tabular}{|l|l|l|l|l|}
\hline $\begin{array}{l}\text { the international fast-food } \\
\text { restaurants that have } \\
\text { negative publicity (Intent2) }\end{array}$ & & & & \\
\hline $\begin{array}{l}\text { I m motivated to visit the } \\
\text { international fast-food } \\
\text { restaurants which have } \\
\text { negative publicity (Intent3) }\end{array}$ & 3.160 & 1.903 & 0.693 & -0.685 \\
\hline $\begin{array}{l}\text { I will try to visit the } \\
\text { international fast-food } \\
\text { restaurants which have } \\
\text { negative publicity (Intent4) }\end{array}$ & 3.594 & 1.908 & 0.931 & -0.785 \\
\hline $\begin{array}{l}\text { Behavior (Behav) have } \\
\text { I hisited the } \\
\text { international fast-food } \\
\text { restaurants that have } \\
\text { negative publicity. (Behav1) }\end{array}$ & 8.419 & 7.816 & 0.725 & 0.925 \\
\hline $\begin{array}{l}\text { I visit the international fast- } \\
\text { food restaurants which have } \\
\text { negative publicity more than } \\
\text { one time per week } \\
\text { (Behav2) }\end{array}$ & 6.639 & 7.654 & 0.659 & 0.915 \\
\hline
\end{tabular}

Table 3 Results of Composite reliability, Cronbach's alpha, Average Variance Extracted, and variance inflation factors

\begin{tabular}{|c|c|c|c|c|}
\hline Construct & $\begin{array}{c}\text { Composite } \\
\text { reliability }\end{array}$ & $\begin{array}{c}\text { Cronbach's } \\
\text { alpha }\end{array}$ & AVE & VIF \\
\hline Attitude & 0.876 & 0.810 & 0.641 & 3.855 \\
\hline SubNorm & 0.938 & 0.901 & 0.834 & 4.091 \\
\hline PerBeCon & 0.821 & 0.772 & 0.604 & 2.813 \\
\hline Intent & 0.860 & 0.776 & 0.615 & 1.975 \\
\hline Behav & 0.828 & 0.785 & 0.707 & 1.077 \\
\hline
\end{tabular}

Notes: SubNorm $=$ Subjective Norms; PerBeCon $=$ Perceived behavioral control; Intent $=$ Intention; Behav $=$ Behavior

Table 4 Loadings and cross-loadings of measurement items

\begin{tabular}{|c|c|c|c|c|c|c|}
\hline Items & Attitude & SubNorm & PerBeCon & Intent & Behav & $\begin{array}{c}p \\
\text { value }\end{array}$ \\
\hline Attitude1 & $\mathbf{1 0 . 7 9 4 )}$ & -0.383 & -0.022 & -0.058 & 0.214 & $<0.001$ \\
\hline
\end{tabular}




\begin{tabular}{|c|c|c|c|c|c|c|}
\hline Attitude2 & $\mathbf{( 0 . 7 7 5 )}$ & -0.447 & -0.038 & 0.066 & -0.114 & $<0.001$ \\
\hline Attitude3 & $\mathbf{( 0 . 8 4 1 )}$ & 0.222 & 0.064 & -0.053 & -0.091 & $<0.001$ \\
\hline Attitude4 & $\mathbf{( 0 . 8 7 9 )}$ & 0.484 & -0.010 & 0.039 & 0.019 & $<0.001$ \\
\hline SubNorm1 & -0.018 & $\mathbf{( 0 . 9 0 7 )}$ & -0.097 & 0.115 & 0.000 & $<0.001$ \\
\hline SubNorm2 & -0.082 & $\mathbf{( 0 . 9 3 1 )}$ & -0.030 & -0.031 & 0.018 & $<0.001$ \\
\hline SubNorm3 & 0.102 & $\mathbf{( 0 . 9 0 2 )}$ & 0.128 & -0.084 & -0.018 & $<0.001$ \\
\hline PerBeCon1 & -0.038 & 0.686 & $\mathbf{( 0 . 7 5 4 )}$ & -0.225 & -0.038 & $<0.001$ \\
\hline PerBeCon2 & -0.063 & -0.546 & $\mathbf{( 0 . 7 7 5 )}$ & -0.092 & 0.131 & $<0.001$ \\
\hline PerBeCon3 & 0.096 & -0.306 & $\mathbf{( 0 . 8 0 2 )}$ & 0.300 & -0.091 & $<0.001$ \\
\hline Intent1 & -0.002 & -0.331 & 0.418 & $\mathbf{( 0 . 8 6 0 )}$ & 0.111 & $<0.001$ \\
\hline Intent2 & 0.067 & -0.140 & 0.101 & $\mathbf{( 0 . 9 1 3 )}$ & 0.028 & $<0.001$ \\
\hline Intent3 & 0.173 & 0.212 & -0.226 & $\mathbf{( 0 . 8 0 0 )}$ & -0.081 & $<0.001$ \\
\hline Intent4 & -0.400 & 0.489 & -0.546 & $\mathbf{( 0 . 4 9 7 )}$ & -0.112 & $<0.001$ \\
\hline Behav1 & -0.007 & 0.097 & -0.077 & 0.015 & $\mathbf{( 0 . 8 4 1 )}$ & $<0.001$ \\
\hline Behav2 & 0.007 & -0.097 & 0.077 & -0.015 & $\mathbf{( 0 . 8 4 1 )}$ & $<0.001$ \\
\hline
\end{tabular}

Notes: SubNorm $=$ Subjective Norms; PerBeCon $=$ Perceived behavioral control; Intent $=$ Intention; Behav $=$ Behavior

- Bolded items are factor loadings

Table 5 Correlations and square roots of AVE

\begin{tabular}{|c|c|c|c|c|c|}
\hline & Attitude & SubNorm & PerBeCon & Intent & Behav \\
\hline Attitude & $(0.800)$ & & & & \\
\hline SubNorm & 0.747 & $(0.913)$ & & & \\
\hline PerBeCon & 0.715 & 0.736 & $(0.777)$ & & \\
\hline Intent & 0.598 & 0.592 & 0.671 & $(0.784)$ & \\
\hline Behav & 0.185 & 0.207 & 0.116 & 0.219 & $(0.841)$ \\
\hline
\end{tabular}

Notes: SubNorm $=$ Subjective Norms; PerBeCon $=$ Perceived behavioral control; Intent= Intention; Behav $=$ Behavior

\section{STRUCTURAL MODEL ASSESSMENT}

The next stage of analysis, significance and strength of the hypothesized relationships among latent variables (Wunderlich, 2013) in the research model were calculated. The model explains 
$49 \%$ of the variance of the intention of international fast food restaurants' guests towards negative publicity and $5 \%$ of the variance of the behavior of international fast food restaurants' guests towards negative publicity. Structural equation modeling was used to test the research hypotheses. The global fit indicators were acceptable, Average path coefficient $($ APC $)=0.218, \mathrm{P}<0.001$, Average Rsquared $(\mathrm{ARS})=0.269, \quad \mathrm{P}<0.001, \quad$ Average adjusted Rsquared $($ AARS $)=0.263, \mathrm{P}<0.001$, Average block VIF $(\mathrm{AVIF})=$ 2.361 , and Goodness of fit $(\mathrm{GoF})=0.428$.

The estimated standardized structural coefficients of the hypothesized relationships between constructs and their significance are showed in table 6. The results declared that all hypothesized relationships are accepted.

Table 6 Results of hypotheses testing

\begin{tabular}{|c|c|c|c|c|}
\hline Hypothesis & Path direction & $\begin{array}{c}\text { Beta } \\
\text { Value }(\beta)\end{array}$ & $\begin{array}{c}\mathbf{P} \\
\text { Value }\end{array}$ & Result \\
\hline $\mathrm{H} 1$ & Attitude $\longrightarrow$ Intent & 0.12 & $=0.01$ & Accepted \\
\hline $\mathrm{H} 2$ & SubNorm $\longrightarrow$ Intent & 0.13 & $<0.01$ & Accepted \\
\hline $\mathrm{H} 3$ & PerBeCon $\longrightarrow$ Intent & 0.50 & $<0.01$ & Accepted \\
\hline $\mathrm{H} 4$ & Intent $\longrightarrow$ Behav & 0.24 & $<0.01$ & Accepted \\
\hline $\mathrm{H} 5$ & PerBeCon $\longrightarrow$ Behav & 010 & $=0.03$ & Accepted \\
\hline
\end{tabular}

Notes: SubNorm $=$ Subjective Norms; PerBeCon $=$ Perceived behavioral control; Intent $=$ Intention; Behav $=$ Behavior

Table (6) declares that all hypotheses of the study are supported; the first hypothesis that predicted that attitude would positively affect intention to visit the international fast-food restaurants that have negative publicity $(\beta=0.12, p=0.01)$. With regard to $\mathrm{H} 2$, the findings supported that the subjective norms were positively related to intention $(\beta=0.13, p=<0.01)$. Hypothesis $\mathrm{H} 3$ predicted that perceived behavioral control was positively affect to intention $(\beta=$ $0.50, \mathrm{p}=<0.01), \mathrm{H} 4$ predicted that intention was positively affect to behavior of international fast food restaurants' guests towards negative publicity $(\beta=0.24, \mathrm{p}=<0.01)$ and $\mathrm{H} 5$ predicted that perceived behavioral control was positively affect to behavior $(\beta=$ $0.10, \mathrm{p}=0.03)$. 
Figure 2 PLS results of research model

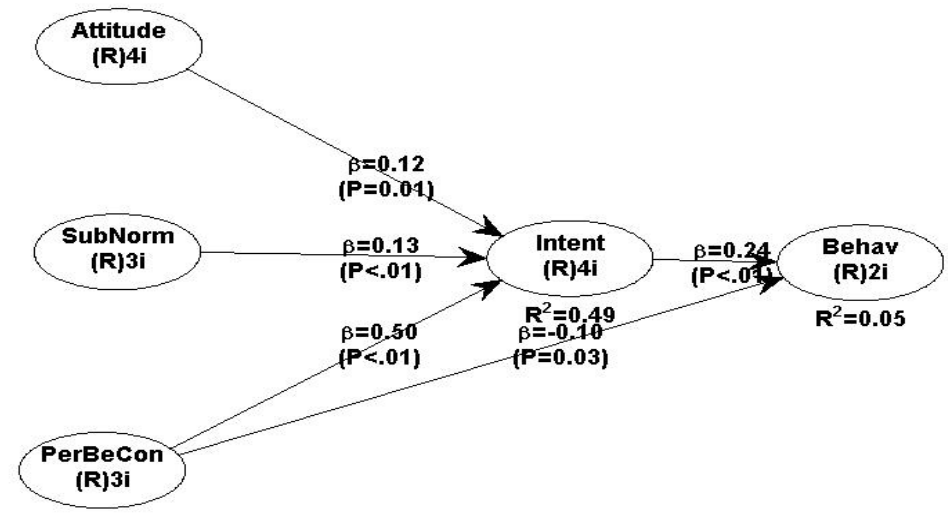

Notes: SubNorm $=$ Subjective Norms; PerBeCon $=$ Perceived behavioral control; Intent $=$ Intention; Behav $=$ Behavior

\section{TESTING OF MEDIATION}

To examine the mediating influence, the researcher performed Preacher and Hayes, (2008) approach. Table 7 declared that attitude was not significant predictor of behavior of international fast food restaurants' guests towards negative publicity. The subjective norms were no longer a significant predictor of the behavior $(\mathrm{p}=0.11)$ after controlling for the mediator. The indirect effects of perceived behavioral control was significant on behavior of international fast food restaurants' guests towards negative publicity ( $\mathrm{p}<0.023$ ).

Table 7 Testing of Mediation

\begin{tabular}{|c|c|c|c|c|c|c|c|c|}
\hline & \multirow[b]{2}{*}{ Path a } & \multirow[b]{2}{*}{ Path b } & \multirow{2}{*}{$\begin{array}{l}\text { Indirect } \\
\text { Effect }\end{array}$} & \multirow[b]{2}{*}{ SE } & \multirow[b]{2}{*}{ t-value } & \multicolumn{2}{|c|}{$\begin{array}{c}\text { Bootstrapped Confidence } \\
\text { Interval }\end{array}$} & \multirow[t]{2}{*}{$\begin{array}{c}\mathbf{P} \\
\text { Value }\end{array}$} \\
\hline & & & & & & $95 \%$ LL & $95 \% \mathrm{UL}$ & \\
\hline Attitude $\rightarrow$ Behav & 0.12 & 0.23 & 0.03 & 0.04 & 0.73 & -0.05 & -0.05 & 0.11 \\
\hline SubNorm $\rightarrow$ Behav & 0.13 & 0.23 & 0.03 & 0.04 & 0.79 & -0.19 & -0.05 & 0.11 \\
\hline PerBeCon $\rightarrow$ Behav & 0.49 & 0.23 & 0.12 & 0.06 & 210 & -0.23 & 0.01 & 0.023 \\
\hline
\end{tabular}

Notes: SubNorm $=$ Subjective Norms; PerBeCon $=$ Perceived behavioral control; Behav $=$ Behavior

\section{DISCUSSION AND CONCLUSION}

The aim of this study was to predict the behavior of international fast food restaurants' guests towards negative publicity. The researcher applied the theory of planned theory. The final integrated model explains $49 \%$ of the variance of the intention of international fast 
food restaurants' guests towards negative publicity and 5\% of the variance of the behavior of international fast food restaurants' guests towards negative publicity. Furthermore, the findings of the current research provide both theoretical and practical implications for understanding the determinants of behavior of international fast food restaurants' guests towards negative publicity.

Attitude, subjective norms, perceived behavioral control would positively affect intention to visit the international fast-food restaurants that have negative publicity. Intention had positive impact on behavior of international fast food restaurants' guests towards negative publicity. These results are in line with previous studies e.g., (Berger, Sorensen, \& Rasmussen, 2010; Smith, 2005; Yu, 2016). Negative publicity can help an organization and has had a positive effect on generating interest, particulary among audiences (Smith, 2005).

Whereas conventional wisdom suggests that any publicity is good publicity, negative publicity increase purchase probability by making persons more aware of the brand (Berger et al., 2010). Usually, the international fast food restaurants expanded quickly and gained high brand awareness (Cooke \& Rowley, 2010). Customers' level of brand awareness is a significant factor in defining their responses to negative publicity, and provides an understanding into why some customers are invulnerable to the impacts of negative publicity.

The response patterns between customers with either high or low level of brand awareness are very dissimilar. While the attitude of customers with a high level of brand awareness keeps intake to negative publicity, the attitude of their counterparts tends to be influenced by the negative effect. Higher brand awareness brings better product evaluation, product likeness, and purchase intention (Sherrell et al., 1985; Shimp, 2007; Yu, 2016).

The results of study are not consistent with previous studies e.g., (Ahluwalia, Burnkrant, \& Unnava, 2000; Bowie \& Buttle, 2004; Sago \& Hinnenkamp, 2014; Shimp, 2007). Negative information conveyed by a trustworthy source, such as publicity, is may be more destructive than the same information presented by a less credible source, such as advertising (Ahluwalia et al., 2000). Negative publicity influences consumer behavior - even towards customers' preferred brands. (Sago\& Hinnenkamp, 2014). Negative publicity which weakens the brand's position in the market (Bowie \& Buttle, 
2004). Establishments fall when negative publicity reaches the media (Shimp, 2007). Negative publicity would effect greater than positive publicity (Maeder, Yamamoto, \& Zannella, 2016).

\section{IMPLICATIONS}

The present study results have declared some important implications for the fast food restaurants' management and academic researchers as well as making a significant contribution to the body of knowledge. First, Customer trust and brand awareness are relevant when the negative publicity published and spread. Customer trust and brand awareness might lead to positive behavioral intentions when they exist. They might drive relationships between international fast food restaurants and customers and overcome the negative publicity. Therefore, the management of fast food restaurants should try to build customer trust and brand awareness through satisfying customers' needs and wants.

Second, the management of fast food restaurants should keep trying to build loyalty. Building loyalty is possible to assume that by supporting customer trust towards fast food restaurants, customer's intentions to visit fast food restaurant will also grow. Face-to-face interactions that let customers become more informed and consequently more trusting (e.g., about food and production process), thereby increasing transparency along the food chain and reducing the impact of negative publicity.

Third, the management of fast food restaurants should not criticize and ignore the media for reporting negative publicity. This behavior may give the impression of haughtiness, and it wastes critical time that could be used to solve the problem if it is serious. A fast food restaurant should also avoid the "no comment" response because it conveys the impression of unsupportiveness and implies responsibility. The management of fast food restaurant as well should prepare news, reports, and perhaps seek professional assistance. Personnel should answer the inquiries from customers and reporters, even when the problem is still unclear.

\section{LIMITATIONS AND FUTURE RESEARCH RESEARCH}

This research is bound by many limitations that also provide fertile grounds for further research. First, a future line of research is to predict the behavior of guests of other categories of hospitality establishments e.g., (local chain fast food restaurants, international chain hotels, independent hotels) towards Negative Publicity. Second, 
the researcher applied theory of planned behavior; other theories may be used in the future research to predict the behavior of international fast food restaurants' guests.

Third, this study indicated that attitude, subjective norms, perceived behavioral control would positively affect intention to visit the international fast-food restaurants that have negative publicity. Intention had positive impact on behavior of international fast food restaurants' guests towards negative publicity. A future line of research may try to find what the reasons that make the negative publicity positive for international fast food restaurants.

\section{REFERENCES}

Ahluwalia, R., Burnkrant, R. E., \& Unnava, H. R. (2000). Consumer Response to Negative Publicity: The Moderating Role of Commitment. Journal of Marketing Research, 37(2), 203-214. https://doi.org/10.1509/jmkr.37.2.203.18734

Ajzen, I. (1991). The theory of planned behavior. Orgnizational Behavior and Human Decision Processes, 50, 179-211. https://doi.org/10.1016/0749-5978(91)90020-T

Al, Y., Locke, S., \& Boulanouar, Z. (2018). Journal of Behavioral and Experimental Finance Islamic financial decision-making among SMEs in the Sultanate of Oman: An adaption of the theory of planned behaviour. Journal of Behavioral and Experimental Finance, (2009). https://doi.org/10.1016/j.jbef.2018.06.001

Anney, V. N. (2014). Ensuring the quality of the findings of qualitative research: looking at trustworthiness criteria. Journal of Emerging Trends in Educational Research and Policy Studies, 5(2), 272-281. https://doi.org/10.3109/08941939.2012.723954

Arnhold, U. (2010). User Generated Branding: Integrating User Generated Content into Brand Management (1st ed.). Wiesbaden: Springer Gabler.

Berger, J., Sorensen, A. T., \& Rasmussen, S. J. (2010). Positive Effects of Negative Publicity: When Negative Reviews Increase Sales, 29(5), 815-827. https://doi.org/10.1287/mksc.1090.0557

Bowie, D., \& Buttle, F. (2004). Hospitality Marketing. Hospitality Marketing, 130-271. https://doi.org/10.1016/B978-0-08-0967912.10009-X

Cameron, R., Ginsburg, H., Westhoff, M., \& Mendez, R. V. (2012). Ajzen's Theory of Planned Behavior and Social Media Use by College Students. American Journal of Psychological Research, $8(1), 1-20$. 
Cheung, M. F. Y., \& To, W. M. (2017). Computers in Human Behavior The in $\mathrm{fl}$ uence of the propensity to trust on mobile users ' attitudes toward in-app advertisements : An extension of the theory of planned behavior, 76, 102-111. https://doi.org/10.1016/j.chb.2017.07.011

Cooke, F. L., \& Rowley, C. (2010). Setting the scene for the Changing Face of Management in China. In F. L. Cooke \& C. Rowley (Eds.), The Changing Face of Management in China (1st ed., pp. 1-16). New York: Routledge Taylor \& Francis Group.

Dow, K., Watson, M., Greenberg, P., \& Greenberg, R. (2012). Understanding Participation: Situational Participation, Intrinsic Involvement, and Influence. In M. . Epstein \& J. . Lee (Eds.), Advances in Management Accounting (1st ed., pp. 25-48). Bingley: Emerald Group Publishing Limited.

Dufour, J.-M., Khalaf, L., \& Beaulieu, M.-C. (2003). Exact skewness-kurtosis tests for multivariate regressions with applications to linear asset pricing models. Oxford Bulletin of Economics and Statistics, 65(Supplement), 891-.

Fornell, C., \& Larcker, D. F. (1981). Evaluating structural equation models with unobservable variables and measurement error. Journal of Marketing Research, 18(1), 39-50.

Frater, J., Kuijer, R., \& Kingham, S. (2017). Why adolescents don't bicycle to school: Does the prototype/willingness model augment the theory of planned behaviour to explain intentions? Transportation Research Part F: Traffic Psychology and Behaviour, 46, 250-259. https://doi.org/10.1016/j.trf.2017.03.005

Hair, J., Hult, T., Ringle, C., \& Sarstedt, M. (2016). A Primer on Partial Least Squares Structural Equation Modeling (PLS-SEM) (2nd ed.). Thousand Oaks: SAGE Publications.

Halder, P., Pietarinen, J., Havu-Nuutinen, S., Pöllänen, S., \& Pelkonen, P. (2016). The Theory of Planned Behavior model and students' intentions to use bioenergy: A cross-cultural perspective. Renewable Energy, 89, 627-635. https://doi.org/10.1016/j.renene.2015.12.023

Henry C. Thode. (2002). Testing For Normality (!st ed.). New York: Marcel Dekker Inc. Retrieved from https://books.google.com.eg/books?id=gbegXB4SdosC\&printsec $=$ frontcover $\# \mathrm{v}=$ onepage $\& \mathrm{q} \& \mathrm{f}=$ false

Henseler, J., Ringle, C. M., \& Sarstedt, M. (2014). A new criterion for assessing discriminant validity in variance-based structural equation modeling. Journal of the Academy of Marketing 
Science, 43(1), 115-135. https://doi.org/10.1007/s11747-0140403-8

Henseler, J., Ringle, C. M., \& Sinkovics, R. R. (2009). The use of partial least squares path modeling in international marketing. Advances in International Marketing, 20(January), 277-319. https://doi.org/10.1108/S1474-7979(2009)0000020014

Ho, Y., Im, J., Eun, S., \& Severt, K. (2018). International Journal of Hospitality Management The theory of planned behavior and the norm activation model approach to consumer behavior regarding organic menus. International Journal of Hospitality Management, 69(March 2017), 21-29. https://doi.org/10.1016/j.ijhm.2017.10.011

Hoeksma, D. L., Gerritzen, M. A., Lokhorst, A. M., \& Poortvliet, P. M. (2017). An extended theory of planned behavior to predict consumers' willingness to buy mobile slaughter unit meat. Meat Science, 128 , $15-23$. https://doi.org/10.1016/j.meatsci.2017.01.011

Holdershaw, J., \& Gendall, P. (2008). Understanding and predicting human behaviour. In ANZCA08 Conference, Power and Place. Wellington.

Hsu, C. H. C., \& Powers, T. (2002). Marketing Hospitality (3rd ed.). NewYork: John Wiley \& Sons, Inc.

Jiang, C., Zhao, W., Sun, X., Zhang, K., \& Zheng, R. (2016). Computers in Human Behavior The effects of the self and social identity on the intention to microblog: An extension of the theory of planned behavior. Computers in Human Behavior, 64, 754-759. https://doi.org/10.1016/j.chb.2016.07.046

Kamaruddin, K., \& Abeysekera, I. (2013). Intellectual Capital and Public Sector Performance (1st ed.). Bingley: Emerlad Group Publishing Limited.

Khan, M. (2006). Consumer Behaviour and Advertising Management (1st ed.). New Delhi: New Age Inernational (P) Limited, Publishers.

Kim, S. H., Carvalho, J. P., \& Cooksey, C. E. (2007). Exploring the effects of negative publicity: News coverage and public perceptions of a university. Public Relations Review, 33(2), 233235. https://doi.org/10.1016/j.pubrev.2007.02.018

Kotler, P. (2002). Marketing Management, Millenium Edition. Marketing Management (10th ed.). Boston: Pearson Custom Publishing. https://doi.org/10.1016/0024-6301(90)90145-T

Kovacevic, N., Abdi, H., \& Beaton, D. (2013). Revisiting PLS Resampling: Comparing Significance Versus Reliability Across 
Range of Simulations. In H. Abdi, W. Chin, V. E. Vinzi, G. Russolillo, \& L. Trinchera (Eds.), New Perspectives in Partial Least Squares and Related Methods (1st ed., pp. 159-170). New York: Springer Science \& Business Media.

Lexow, M., \& Edelheim, J. R. (2004). Effects of Negative Media Events on Tourist's Decisions, (November), 51-60.

Li, J., Zuo, J., Cai, H., \& Zillante, G. (2018). Construction waste reduction behavior of contractor employees : An extended theory of planned behavior model approach. Journal of Cleaner Production, 172 1399-1408. https://doi.org/10.1016/j.jclepro.2017.10.138

Lin, C. Y., Oveisi, S., Burri, A., \& Pakpour, A. H. (2017). Theory of Planned Behavior including self-stigma and perceived barriers explain help-seeking behavior for sexual problems in Iranian women suffering from epilepsy. Epilepsy and Behavior, 68, 123128. https://doi.org/10.1016/j.yebeh.2017.01.010

López-Mosquera, N. (2016). Gender differences, theory of planned behavior and willingness to pay. Journal of Environmental Psychology, 45 , $165-175$. https://doi.org/10.1016/j.jenvp.2016.01.006

Lowry, P. B., \& Gaskin, J. (2014). Partial least squares (PLS) structural equation modeling (SEM) for building and testing behavioral causal theory: When to choose it and how to use it. IEEE Transactions on Professional Communication, 57(2), 123146. https://doi.org/10.1109/TPC.2014.2312452

Maeder, E. M., Yamamoto, S., \& Zannella, L. (2016). Putting negative attitudes on the agenda? Not Criminally Responsible Reform Act publicity and juror decision-making. International Journal of Law and Psychiatry, 49, 154-159. https://doi.org/10.1016/j.ijlp.2016.08.010

O'Brien, R. M. (2007). A caution regarding rules of thumb for variance inflation factors. Quality and Quantity, 41(5), 673-690. https://doi.org/10.1007/s11135-006-9018-6

Onkvisit, S., \& Shaw, J. (2004). International Marketing: Analysis and strategy $\left(4^{\text {th }}\right.$ ed.). New York: Routledge Taylor \& Francis Group.

Preacher, K., \& Hayes, A. (2008). Asymptotic and resampling strategies for assessing and comparing indirect effects in multiple mediator models. Behavior Research Methods, 40(3), 879-891.

Raziuddin, K., \& Vaithianathan, S. (2018). A fresh look at understanding Green consumer behavior among young urban Indian consumers through the lens of Theory of Planned 
Behavior,

183 ,

$46-55$.

https://doi.org/10.1016/j.jclepro.2018.02.097

Reyes-Mercado, P. (2016). Eco-Innovations in Emerging Markets:

Analyzing Consumer Behaviour and Adaptability (1st ed.).

London: Palgrave Macmillan.

Rezaei, R., Mianaji, S., \& Ganjloo, A. (2018). Factors affecting farmers' intention to engage in on-farm food safety practices in Iran: Extending the theory of planned behavior. Journal of Rural Studies, 60(February), $152-166$. https://doi.org/10.1016/j.jrurstud.2018.04.005

Röttger, S., Maier, J., Krex-Brinkmann, L., Kowalski, J. T., Krick, A., Felfe, J., \& Stein, M. (2017). Social cognitive aspects of the participation in workplace health promotion as revealed by the theory of planned behavior. Preventive Medicine, 105(July), 104-108. https://doi.org/10.1016/j.ypmed.2017.09.004

Russo, D. A., Stochl, J., Painter, M., Shelley, G. F., Jones, P. B., \& Perez, J. (2015). Use of the Theory of Planned Behaviour to assess factors influencing the identification of students at clinical high-risk for psychosis in 16+ Education. BMC Health Services Research, 15(1), 1-11. https://doi.org/10.1186/s12913-015-1074$\mathrm{y}$

Sago, B., \& Hinnenkamp, C. (2014). THE IMPACT OF SIGNIFICANT NEGATIVE NEWS ON CONSUMER BEHAVIOR TOWARDS FAVORI...: Discovery Service for Universiti Putra Malaysia, 8(1), 65-72. Retrieved from http://ezproxy.upm.edu.my:2124/eds/pdfviewer/pdfviewer?sid=c 240b1ae-cd89-4d18-ac0a-

53aabaecd9cf@sessionmgr4004\&vid=9\&hid=4213

Sherrell, D., Reidenbach, R. E., Moore, E., Wagle, J., \& Spratlin, T. (1985). Exploring consumer response to negative publicity. Public Relations Review, 11(1), 13-28. https://doi.org/10.1016/S0363-8111(85)80057-6

Shi, H., Fan, J., \& Zhao, D. (2017). Predicting household PM2 . 5reduction behavior in Chinese urban areas : An integrative model of Theory of Planned Behavior and Norm Activation Theory. Journal of Cleaner Production, 145, 64-73. https://doi.org/10.1016/j.jclepro.2016.12.169

Shimp, T. (2007). Advertising, Promotion, and Other Aspects of Integrated Marketing Communications (7Th ed.). Natorp Boulevard Mason: Thomson South-Western.

Smith, R. (2005). Strategic Planning for Public Relations (2nd ed.). Ner Gersey: Lawrence Erlbaum Associates, Publishers. 
Tartamella, L. (2001). AZ-MARKETING: Desk Reference Guide (1st ed.). Montreal-Nord,: Houser and Swire Group Inc.

Teo, T., Tsai, L., \& Yang, C.-C. (2013). Applying Structural Equation Modeling (SEM) in Educational Research: An Introduction. In M. Swe (Ed.), Application of Structural Equation Modeling in Educational Research and Practice (1st ed., pp. 11-12). Rotterdam: Sense Publishers.

Thorhauge, M., Haustein, S., \& Cherchi, E. (2016). Accounting for the Theory of Planned Behaviour in departure time choice. Transportation Research Part F: Psychology and Behaviour, 38, 94-105. https://doi.org/10.1016/j.trf.2016.01.009

Wolf, E. J., Harrington, K. M., Clark, S. L., \& Miller, M. W. (2015). Sample Size Requirements for Structural Equation Models: An Evaluation of Power, Bias, and Solution Propriety. National Institutes of Health, 76(6), 913-934. https://doi.org/10.1177/0013164413495237.Sample

Wooldridge, J. (2009). Introductory Econometrics: A Modern Approach (4th ed.). Mason: South-Western Cengage Learning.

Wunderlich, P. (2013). Green Information Systems in the Residential Sector: An Examination of the Determinants of Smart Meter Adoption (1st ed.). New York: Springer.

Youn, H., Lim, B. I., \& Jin, H. J. (2012). Differential effects of negative publicity on beef consumption according to household characteristics in South Korea. Health Policy, 106(2), 138-148. https://doi.org/10.1016/j.healthpol.2012.03.005

$\mathrm{Yu}$, S.-F. (2016). Attitude toward Negative Publicity: The Moderating Influence of Brand Awareness. Global Journal of Emerging Trends in E-Business, Marketing and Consumer Psychology (GJETeMCP) An Online International Research JournalGJETeMCP) An Online International Research Journal, 2(2), 2311-3170.

Zhou, H., Romero, S. B., \& Qin, X. (2016). An extension of the theory of planned behavior to predict pedestrians' violating crossing behavior using structural equation modeling. Accident Analysis and Prevention, 95, 417-424. https://doi.org/10.1016/j.aap.2015.09.009 